ISSN: 2224-0616

Int. J. Agril. Res. Innov. \& Tech. 4 (1): 64-69, J une, 2014

Available online at http:// www.ijarit.webs.com

\title{
NUTRIENT DISTRIBUTION IN FLOWERING STEMS, NUTRIENT REMOVAL AND FERTILIZATION OF THREE PROTEACEAE CULTIVARS
}

\author{
M.M. Hernández, M. Fernández-Falcón and C.E. Álvarez*
}

Received 14 February 2014, Revised 5 June 2014, Accepted 28 June 2014, Published online 30 June 2014

\begin{abstract}
Several parameters of flowering stems of two cultivars of protea Leucospermum cordifolium (Knight) Fourc ('Succession II' and 'Tango') and one of protea Protea L. (Protea susannaex magnifica 'Susara') were studied in different commercial plantations. These included length and weight measures, nutrient concentrations of detached parts (flower heads, leaves and stems), and removal of nutrients of harvested flowers. A base for fertilization was also calculated. Harvested flowers of 'Susara' removed more P, K and Cu than 'Succession II' and Tango', and more Ca and Fe than 'Tango'. 'Succession II' showed the highest Zn removal. The P and Cu removal by the crop of 'Susara' were significantly higher than those of both Leucospermum cultivars, while $\mathrm{K}, \mathrm{Ca}$, and Fe outputs of 'Susara' exceeded only those of 'Tango'. The nutrient top removals amounted to $4.55 \mathrm{~g} \mathrm{~m}^{-2}$ of $\mathrm{N}, 0.48 \mathrm{~g} \mathrm{~m}^{-2}$ of $\mathrm{P}$, and $5.26 \mathrm{~g}$ $\mathrm{m}^{-2}$ of $\mathrm{K}$. Data as a base to supply fertilizer to each cultivar are given, with N:P:K ratios of 1:0.08:0.87 for 'Succession II', 1:0.08:0.83 for 'Tango' and 1:0.10:1.27 for 'Susara'.
\end{abstract}

Keywords: Leucospermum, Succession II, Susara, Tango

Instituto de Productos Naturales y Agrobiología, Consejo Superior de Investigaciones Científicas, Avenida Astrofísico Francisco Sánchez 3, 38206 La Laguna, Tenerife, Canary Islands, Spain.

*Corresponding author's email: carlose@ipna.csic.es (C.E. Álvarez)

\section{Introduction}

Leucospermum and Protea are genera of the Proteaceae family that have obtained an increasing importance in the market of cut flowers worldwide, where they are known as proteas. Most of the species are native to Africa and Australia, which are also the main producers together with USA (Malan, 2012).

It is difficult to get a clear idea of the distribution of nutrients within the flowering stems in many proteas (genera Leucadendron, Leucospermum and Protea), because the chosen tissues are different depending on the authors. Cresswell (1991) took stems, young leaves and old leaves of Leucadendron cv. Harvest, and Protea neriifolia cv's Satin mink and Pink Ice, where he distinguished among optimum, high and toxic levels of phosphorous. Maier et al. (1995) analysed the nutrient contents of stems and leaves, axillary buds and flowers separately. The nitrogen and potassium contents of stems and leaves significantly exceeded those of the other fractions of the flowering stem, and the flowers showed the lowest calcium and magnesium concentrations. González et al. (2008) divided commercial flowers of five Leucospermum cultivars into flower head, half-distal and halfproximal stems, and half-proximal and half-distal leaves. Nutrient levels within every organ presented significant variations among cultivars. The nutrients related with the length of the stems also varied. Fernández-Falcón et al. (2008) observed that nutrient percentages in flower heads, leaves and stem of the flowering stem varied within the cultivar of Leucospermum.

These studies may help to determine nutrient removal of the crop by taking into account the nutrient content of the plant part that is generally harvested (Mengel and Kirkby, 2001). In the case of protea for cut flower there is very limited information in the literature that includes wastage by pruning and fallen foliage, which could represent up to $54 \%$ of the total nutrients removed by a protea plant (León, 2011).

Claassens (1986) reported removal of $5.3 \mathrm{~kg} \mathrm{ha}^{-1}$ $\mathrm{N}$ by flowering stems of Protea neriifolia, and $7.5 \mathrm{~kg} \mathrm{ha}^{-1} \mathrm{~N}$ by Leucospermum cordifolium. He also did assays with L. cordifolium in sand hydroponic cultures, and obtained higher nutrient removals $30.0 \mathrm{~kg} \mathrm{ha}^{-1} \mathrm{~N}$, as well as increased values of $\mathrm{P}, \mathrm{K}, \mathrm{Ca}$, and $\mathrm{Mg}$. $\mathrm{He}$ concluded that protea crop removes low quantities of nutrients, and that fertilization with $\mathrm{N}$ could increase the productions in very acid and sandy soils. However, in a controlled 
fertilization experiment, Hawkins et al. (2007) reported that Leucospermun 'Succession' and Leucadendron 'Safari Sunset' acquired more N amounts than were supplied, but increasing $\mathrm{N}$ fertilization decreased their growth. They also found than 'Safari Sunset' removed $18 \mathrm{~g} \mathrm{~N}$ per plant, and 'Succession' 5.,5 g N per plant. Maier et al. (1995) detected N removal by Protea cv. Pink Ice of 26-43 kg ha-1. Fernández-Falcón et al. (2008) reported higher amounts of N removed by the crops of L. patersonii and four L. cordifolium cultivars that reached nearly $150 \mathrm{~kg} \mathrm{ha}^{-1}$ in some instances. In a compilation of works made in South Australia, Reid (2003) showed annual N exportations of Protea 'Pink Ice' and Leucadendron 'Silvan Red' which were 27.2 and 15.3 g plant ${ }^{-1}$, respectively.

The study of nutrient removal of leaves and flowering stem of Leucadendron 'Silvan Red' and 'Safari Sunset' lead Cecil et al. (1995) to recommend annual applications of $\mathrm{N}$ and $\mathrm{Ca}$ at 20-30 g/plant, and $\mathrm{Mg}$ and $\mathrm{K}$ at 10-15 g/plant, that would meet the nutrient needs of both cultivars. Reid (2003) suggested that, to calculate the fertilizer needs based on the nutrient extractions of the crop, inefficiency of fertilizer by leaching should be taken into account, and proposed to apply at least double quantities of nutrients than the removed ones.

All these data show that nutrient removal and fertilization needs are different depending on genus, species and cultivars. The present paper aims to broaden the knowledge of nutrient distribution within the flowering stem of protea genera Leucospermum and Protea, and their nutrient removal. Besides, a base for fertilization was also calculated.

\section{Materials and Methods}

Two cultivars of Leucospermum cordifolium (Knight) Fourc ('Succession II' and 'Tango'), and one of Protea L. (Protea susannae $\mathrm{x}$ magnifica 'Susara') were studied in commercial plantations located in eight municipalities of La Palma (Canary Islands, Spain), distributed around the island, to obtain the general averages of the parameters listed below. The cultivars were selected by their very high commercial importance. Soils were Inceptisols Andepts and Ultisol Udults.

Flowering stems of commercial quality ( $30 \mathrm{~cm}$ or more of length, straight and without defects in the cases of 'Succession' and 'Tango' and equal to or longer than $45 \mathrm{~cm}$ for 'Susara') were taken in the field from each of the mentioned cultivars, during the harvest season (January to April) of the years
2009 and 2010. Samples of each farm consisted of three replications per cultivar, with three flowering stems per replication.

Lengths of the flowering stems were measured before cutting them into different parts: flower head, leaves, and stem. Fresh weight and dry weight of each plant part were determined, as well as their nutrient concentrations. Dry weights were measured after drying each plant part in an oven at $80^{\circ} \mathrm{C}$, and weighting them till no difference in weight was detected between two weightings.

For chemical analysis purposes, the samples were washed in distilled water and dried in an oven at $80^{\circ} \mathrm{C}$, after which they were ground to powder. One $g$ of the powder was ashed in an oven at $480^{\circ} \mathrm{C}$ and then mineralized by dry ashing with $6 \mathrm{M}$ hydrochloric acid (Chapman and Pratt, 1961). The P, K, Ca, Mg, Cu, Fe, Mn and $\mathrm{Zn}$ concentrations were determined by ICP Perkin-Elmer. Nitrogen was determined by the Kjeldahl method (Cottenie, 1980).

The nutrient content of the flowering stem for each cultivar was obtained from the concentrations of nutrients of the flowering stems and dry mass weight. The nutrient removal of each cultivar was calculated from the nutrient content of the whole flower and the flower yields by square meter that amounted to 30 flowers in 'Succession', 25 in 'Tango' and 10 in 'Susara'.

Production data were collected from the Association of Protea Growers of La Palma Island. Data were subjected to one-way variance analysis, using Tuckey $b$ test at $p=0.05$, by SPSS 15.0 statistical software. Correlation and regression analysis were also performed, but no important relationship among nutrients and/ or other studied parameters was found. Soil chemical analysis has been reported elsewhere (Álvarez et al. 2012).

\section{Results and Discussion}

Nutrient concentration in the different plant parts of the flowering stems of the different cultivar

Flower: Succession II cultivar showed the highest concentrations of $\mathrm{N}, \mathrm{Mg}, \mathrm{Na}$, and $\mathrm{Zn}$ (Table 1), though not significantly higher than 'Tango' for Mg. The Na concentration of 'Susara' flowers was significantly lower than 'Succession' and 'Tango'. The other nutrients presented similar concentrations among the cultivars. 
Table 1. Nutrient concentration of different plant parts for a protea cultivar on a dry mass base for 2009 and 2010

\begin{tabular}{|c|c|c|c|c|c|c|c|c|c|c|c|}
\hline \multirow{2}{*}{ Cultivar } & \multirow{2}{*}{$\begin{array}{l}\text { Plant } \\
\text { part }\end{array}$} & \multicolumn{6}{|c|}{$\mathrm{g} \mathrm{kg}^{-1}$} & \multicolumn{4}{|c|}{$\mathrm{mg} \mathrm{kg}^{-1}$} \\
\hline & & $\mathrm{N}$ & $\mathrm{P}$ & $\mathrm{K}$ & $\mathrm{Ca}$ & $\mathrm{Mg}$ & $\mathrm{Na}$ & $\mathrm{Fe}$ & $\mathrm{Mn}$ & $\mathrm{Cu}$ & $\mathrm{Zn}$ \\
\hline \multirow{3}{*}{$\begin{array}{l}\text { Succes- } \\
\text { sion }\end{array}$} & Head & $8.16 \mathrm{a}$ & 0.64 & 7.04 & $2.44 \mathrm{~b}$ & 1.58 & 6.17 & 35 & $83 \mathrm{~b}$ & 5 & 19 \\
\hline & Leaf & $10.56 \mathrm{a}$ & 0.56 & 4.52 & 9.16a & 2.01 & 6.26 & 60 & $315 a$ & 4 & 21 \\
\hline & Stem & $5.31 \mathrm{~b}$ & 0.59 & 8.69 & $3.72 \mathrm{~b}$ & 1.45 & 3.27 & 46 & $104 \mathrm{~b}$ & 5 & 14 \\
\hline \multirow{3}{*}{ Tango } & Head & $6.08 \mathrm{~b}$ & 0.59 & $5.87 \mathrm{a}$ & $1.94 \mathrm{~b}$ & $1.42 \mathrm{~b}$ & $5.22 \mathrm{a}$ & $32 \mathrm{~b}$ & $86 \mathrm{~b}$ & 8 & 12 \\
\hline & Leaf & 10.31a & 0.52 & $4.28 \mathrm{~b}$ & $9.12 \mathrm{a}$ & 2.11a & $5.68 \mathrm{a}$ & $61 \mathrm{a}$ & $553 a$ & 7 & 15 \\
\hline & Stem & $5.72 \mathrm{~b}$ & 0.39 & $6.19 \mathrm{a}$ & $3.15 \mathrm{~b}$ & $1.51 \mathrm{~b}$ & $3.38 \mathrm{~b}$ & $37 \mathrm{~b}$ & $112 \mathrm{~b}$ & 7 & 11 \\
\hline \multirow{3}{*}{ Susara } & Head & 5.35 & 0.50 & 6.36 & 2.40 & $0.91 b$ & $1.23 \mathrm{a}$ & 34 & $83 \mathrm{~b}$ & 11 & $10 \mathrm{~b}$ \\
\hline & Leaf & 6.08 & 0.43 & 3.75 & 8.03 & $1.43 a$ & $1.21 a$ & 38 & 199a & 7 & $11 \mathrm{~b}$ \\
\hline & Stem & 4.92 & 0.63 & 7.34 & 2.70 & $0.62 \mathrm{c}$ & $0.66 \mathrm{~b}$ & 36 & $200 a$ & 11 & $20 a$ \\
\hline
\end{tabular}

Different letters following the data within each column of each cultivar denote significant differences at $\mathrm{p}=0.05$ level.

Maier et al. (1995) found in Protea 'Pink Ice' lower concentrations of $\mathrm{N}, \mathrm{K}, \mathrm{Ca}, \mathrm{Mg}, \mathrm{Na}, \mathrm{Cu}, \mathrm{Mn}$ and $\mathrm{Zn}$ than those detected in this study, although the level of Na equalled that of 'Susara', and the concentration of $\mathrm{Zn}$ was higher than those of 'Susara' and 'Tango'. Phosphorus presented similar levels than the cultivars of this assay, while Fe exceeded them.

González et al. (2008) determined in five Leucospermum cultivars $\mathrm{N}$ and $\mathrm{Zn}$ concentrations close to those of this study. The same happened with $\mathrm{Fe}$ but only in two of the five cultivars. On the other hand, they observed $\mathrm{P}, \mathrm{Ca}, \mathrm{Mg}, \mathrm{Na}$, and $\mathrm{Mn}$ higher levels, where Mg became two to three times higher. Potassium and $\mathrm{Cu}$ concentrations in this study exceeded the ones detected by these authors, though $\mathrm{K}$ levels were lower than in some cultivars.

There were differences of some nutrient concentrations between cultivars of Leucospermum, as well as between those of Leucospermum and Protea, confirming what the literature mentioned on this subject (Parvin 1986; Cecil et al., 1995; Montarone et al., 2003). Na presented very high concentrations, specially in the cultivar 'Succession II', a fact that Alvarez et al. (2012) had pointed out for proteas.

Leaf: The leaves of 'Susara' cultivar exhibited significantly lower $\mathrm{N}, \mathrm{Mg}, \mathrm{Na}, \mathrm{Fe}, \mathrm{Mn}$ and $\mathrm{Zn}$ compared to the other cultivars (Table 1), though Mn concentration resembled that of 'Succession II', and Zn that of 'Tango'.
The concentrations of $\mathrm{N}, \mathrm{P}, \mathrm{K}, \mathrm{Ca}, \mathrm{Mg}$ and $\mathrm{Na}$ obtained by González et al. (2008) in several Leucospermum cultivars exceeded those detected in this study. Iron followed the same trend, but its values in one of the cultivars matched the ones of 'Succession II' and Tango'. On the contrary, Mn levels of this study surpassed the concentrations found by these authors in three cultivars, while the levels of $\mathrm{Zn}$ and Cu were similar.

The great accumulation of $\mathrm{Na}$ observed in the flower head of 'Succession II' appears also in the leaves, though in the case of the leaves 'Tango' presents similar $\mathrm{Na}$ levels. They remained significantly lower in 'Susara'. Moreover, the two genera presented notable differences in the concentration of some nutrients.

Stems: The stems of both 'Succession II' and 'Tango' had higher levels of $\mathrm{Mg}$ and $\mathrm{Na}$ compared to 'Susara' (Table 1). On the contrary, 'Succession II' stems showed the lowest concentration of $\mathrm{Cu}$, while 'Susara' presented the highest one, and that of 'Tango' was intermediate.

Nitrogen, $\mathrm{K}, \mathrm{Mg}, \mathrm{Na}, \mathrm{Cu}$ and $\mathrm{Mn}$ concentrations fell below those reported by Maier et al. (1995) in Protea 'Pink Ice', though Mg level in 'Susara' was similar, and greater than that of Na. Phosphorus and $\mathrm{Zn}$ values resembled those of this study, while $\mathrm{Ca}$ and Fe exceeded them.

On the other hand, González et al. (2008), in several Leucospermum cultivars, obtained N, P, $\mathrm{K}, \mathrm{Ca}, \mathrm{Mg}, \mathrm{Na}, \mathrm{Fe}$ and $\mathrm{Zn}$ concentrations higher 
than those of this study, with the exception of K in 'Succession II', that was alike. Copper levels did not differ, while Mn behaved without a clear trend.

As in the previous two organs, the concentration of $\mathrm{Na}$ in the stems of both cultivars of Leucospermum exceeded by far that of the cultivar of Protea, while differences of the concentrations of some nutrients between the genera turned up once more.

Fernández-Falcón et al. (2008) found the highest $\mathrm{N}, \mathrm{Ca}, \mathrm{Mg}, \mathrm{Na}$ and $\mathrm{Mn}$ contents in the leaves of five Leucospermum cultivars, and the lowest $\mathrm{P}, \mathrm{K}$ and $\mathrm{Cu}$ in the stems, and $\mathrm{Fe}$ in the flower. Zinc was similar in the three organs. Nevertheless, they found different behaviours of the nutrient contents in some of the cultivars, as has happened in this study. For example, $\mathrm{N}$ was similar in the three studied flower organs of 'Susara', the flower head of 'Succession' had more than the stem, and
'Tango' showed similar values in the stem and the flower head.

Total nutrient concentration of flowering stem on a fresh mass base

Both Leucospermum cultivars presented similar concentration of $\mathrm{N}, \mathrm{Mg}$ and $\mathrm{Na}$ in the entire flowering stems (Table 2), though they significantly exceeded those of the Protea cultivar Susara. No differences were detected in the concentrations of the rest of the nutrients. Their behaviour was closely related to those observed in the detached organs.

Flowering stem length, fresh and dry mass of the different cultivars

Table 3 shows the lengths of flowering stems, as well as the fresh and dry weights of the entire flowering stems and the different studied parts (heads, stems and leaves).

Table 2. Total nutrient concentrations of the flowering stem of different protea cultivars on dry mass base for 2009 and 2010

\begin{tabular}{|c|c|c|c|c|c|c|c|c|c|c|}
\hline \multirow[b]{2}{*}{ Cultivars } & \multicolumn{6}{|c|}{$\mathrm{gkg}^{-1}$} & \multicolumn{4}{|c|}{$\mathrm{mgkg}^{-1}$} \\
\hline & $\mathrm{N}$ & $\mathrm{P}$ & $\mathrm{K}$ & $\mathrm{Ca}$ & $\mathrm{Mg}$ & $\mathrm{Na}$ & $\mathrm{Fe}$ & $\mathrm{Mn}$ & $\mathrm{Cu}$ & $\mathrm{Zn}$ \\
\hline Succession & $8.30 \mathrm{a}$ & 0.59 & 6.75 & 5.10 & $1.68 \mathrm{a}$ & $5.23 \mathrm{a}$ & 47 & 168 & 5 & 18 \\
\hline Tango & $7.46 \mathrm{a}$ & 0.67 & 5.44 & 4.74 & $1.68 \mathrm{a}$ & $4.76 \mathrm{a}$ & 44 & 264 & 7 & 12 \\
\hline Susara & $4.51 \mathrm{~b}$ & 0.52 & 5.82 & 4.38 & $0.99 \mathrm{~b}$ & $1.03 \mathrm{~b}$ & 36 & 161 & 10 & 14 \\
\hline
\end{tabular}

Different letters following the data within each column denote significant differences at $p=0.05$ level.

Table 3. Flowering stem length, fresh and dry mass of different parts of different protea cultivars for 2009 and 2010

\begin{tabular}{|c|c|c|c|c|c|c|c|c|c|}
\hline \multirow[b]{2}{*}{ Cultivars } & \multirow{2}{*}{$\begin{array}{l}\text { Length } \\
\text { (cm) }\end{array}$} & \multicolumn{8}{|c|}{$\mathrm{g}$} \\
\hline & & FFM* & LFM & SFM & FSFM & FDM & LDM & SDM & FSDM \\
\hline Succession & $56.8 \mathrm{~b}$ & $30.4 \mathrm{~b}$ & $22.8 \mathrm{~b}$ & $23.8 \mathrm{~b}$ & $76.8 \mathrm{~b}$ & $5.4 \mathrm{~b}$ & $7.3 \mathrm{~b}$ & $7.0 \mathrm{~b}$ & $19.8 \mathrm{~b}$ \\
\hline Tango & $57.0 \mathrm{~b}$ & $32.2 \mathrm{~b}$ & $24.5 \mathrm{~b}$ & $22.3 \mathrm{~b}$ & $79.7 \mathrm{~b}$ & $6.3 \mathrm{~b}$ & $7.7 \mathrm{~b}$ & $6.8 \mathrm{~b}$ & $20.5 \mathrm{~b}$ \\
\hline Susara & $72.6 \mathrm{a}$ & $95.3 \mathrm{a}$ & $80.8 \mathrm{a}$ & $62.4 \mathrm{a}$ & $238.5 a$ & $32.2 \mathrm{a}$ & $33.1 \mathrm{a}$ & $24.4 \mathrm{a}$ & 89.6 a \\
\hline
\end{tabular}

* FFM = flower fresh mass; LFM = leaf fresh mass; SFM = stem fresh mass; FSFM =flowering stem fresh mass; FDM = flower dry mass; LDM = leaf dry mass; SDM = stem dry mass; FSDM = flowering stem dry mass Different letters following the data within each column denote significant differences at $\mathrm{p}=0.05$ level.

Cultivar 'Susara' presented significantly higher data of all these parameters than the other two cultivars, while 'Succession II' and 'Tango' did not exhibited appreciable differences between them. The observed findings could be expected because 'Succession II' and Tango' come from the same genus (Leucospermum), and 'Susara' from Protea genus that produces longer and heavier flowers.
Total nutrient content of flowering stem on a dry mass base: Leucospermum cultivars 'Succession II' and 'Tango' had similar nutrient contents of the entire flowering stems (Table 4), but 'Susara' Protea cultivar significantly exceeded them. This could be due to the greater size of the Protea 'Susara' cut flowers, as remarked previously.

Table 4. Total nutrient content of the whole flowering stem of different protea cultivars on a dry mass base for 2009 and 2010 .

\begin{tabular}{|c|c|c|c|c|c|c|c|c|c|c|}
\hline \multirow{2}{*}{ Cultivars } & \multicolumn{6}{|c|}{ g flowering stem $^{-1}$} & \multicolumn{4}{|c|}{ mg flowering stem $^{-1}$} \\
\hline & $\mathrm{N}$ & $\mathrm{P}$ & $\mathrm{K}$ & $\mathrm{Ca}$ & $\mathrm{Mg}$ & $\mathrm{Na}$ & $\mathrm{Fe}$ & $\mathrm{Mn}$ & $\mathrm{Cu}$ & $\mathrm{Zn}$ \\
\hline & $0.15 \mathrm{~b}$ & $0.012 \mathrm{~b}$ & $0.13 \mathrm{~b}$ & $0.10 \mathrm{~b}$ & $0.033 \mathrm{~b}$ & 0.11 & $0.9 \mathrm{~b}$ & $3.6 \mathrm{~b}$ & $0.10 \mathrm{~b}$ & $0.34 \mathrm{~b}$ \\
\hline $\begin{array}{l}\text { Tango } \\
\text { Susara }\end{array}$ & $0.41 \mathrm{a}$ & $\begin{array}{l}0.011 \mathrm{~b} \\
0.048 \mathrm{a}\end{array}$ & $\begin{array}{l}0.12 \mathrm{~b} \\
0.53 \mathrm{a}\end{array}$ & $\begin{array}{l}0.10 \mathrm{~b} \\
0.39 \mathrm{a}\end{array}$ & & $\begin{array}{l}0.10 \\
0.09\end{array}$ & $\begin{array}{l}0.9 \mathrm{~b} \\
3.2 \mathrm{a}\end{array}$ & $\begin{array}{l}4.8 \mathrm{~b} \\
14.6 \mathrm{a}\end{array}$ & $\begin{array}{l}0.15 \mathrm{~b} \\
0.80 \mathrm{a}\end{array}$ & $\begin{array}{l}24 \mathrm{~b} \\
28 \mathrm{a}\end{array}$ \\
\hline
\end{tabular}

Different letters following the data within each column denote significant differences at $\mathrm{p}=0.05$ level. 
Fernández-Falcón et al. (2008) observed higher N, P, K, Ca, Mg, Fe and Mn contents compared to this study. Nevertheless, two of the five cultivars investigated by these authors presented lower Mn contents than those of 'Susara'. The levels of $\mathrm{Cu}$ and $\mathrm{Zn}$ detected by these researchers rose above the values found in 'Succession II' and 'Tango', but they were lower than in 'Susara'.
Nutrient removal of the flowering stems per $\mathrm{m}^{2}$. Table 5 shows the nutrient removal of each cultivar. Nitrogen, $\mathrm{Mg}$ and $\mathrm{Mn}$ showed similar outputs in the three cultivars. Tango' presented the lowest outputs of $\mathrm{K}, \mathrm{Ca}$ and $\mathrm{Zn}$, while the other two cultivars had analogous values. On the other hand, 'Susara' flowers removed more $\mathrm{P}$ and $\mathrm{Cu}$ than the other two cultivars, and more $\mathrm{Fe}$ than 'Tango'.

Table 5. Nutrient removal per protea cultivar according to number of flowering stems $\mathrm{m}^{-2}$ for 2009 and 2010

\begin{tabular}{|c|c|c|c|c|c|c|c|c|c|}
\hline \multirow{2}{*}{ Cultivars } & \multicolumn{5}{|c|}{$\mathrm{gm}^{-2}$} & \multicolumn{4}{|c|}{$\mathrm{mg} \mathrm{m}^{-2}$} \\
\hline & $\mathrm{N}$ & $\mathrm{P}$ & $\mathrm{K}$ & $\mathrm{Ca}$ & $\mathrm{Mg}$ & $\mathrm{Fe}$ & Mn & $\mathrm{Cu}$ & $\mathrm{Zn}$ \\
\hline Succession & 4.55 & $0.35 \mathrm{~b}$ & $3.96 \mathrm{~b}$ & $3.12 \mathrm{a}$ & 1.00 & $27.8 \mathrm{ab}$ & 106.2 & $3.33 \mathrm{~b}$ & $10.08 \mathrm{a}$ \\
\hline Tango & 3.51 & $0.27 \mathrm{~b}$ & $2.90 \mathrm{~b}$ & $2.55 \mathrm{~b}$ & 0.91 & $22.7 \mathrm{~b}$ & 120.6 & $3.71 \mathrm{~b}$ & $6.09 \mathrm{~b}$ \\
\hline Susara & 4.13 & $0.48 \mathrm{a}$ & $5.26 \mathrm{a}$ & $3.90 \mathrm{a}$ & 0.88 & $31.7 \mathrm{a}$ & 146.0 & $8.23 \mathrm{a}$ & $12.77 \mathrm{~b}$ \\
\hline
\end{tabular}

Different letters following the data within each column denote significant differences at $\mathrm{p}=0.05$ level.

The nutrient removal far exceeded the N, P, K, Ca and Mg outputs reported by Claassens (1986) for P. neriifolia and L. cordifolium grown in the field, though they approached those of $\mathrm{N}$ and $\mathrm{P}$ when these plants were grown in hydroponics. The outputs of N and P by Protea 'Pink Ice' observed by Maier et al. (1995) and Reid (2003) were more similar, and even some values of $\mathrm{P}$ and $\mathrm{Ca}$ surpassed the removals detected in this study. The removal of $\mathrm{Zn}$ and Fe exceeded that found by Reid (2003) for 'Pink Ice', while the opposite happened with Mg. Fernández-Falcón et al. (2008) reported different amounts of nutrients removed by crops of Leucospermum. They found nutrient removals higher, lower or similar to those observed in this study, depending upon the cultivar.

Though the nutrient content per cut flower of 'Susara' exceeded those of the other cultivars, as stated before, its yields were clearly lower. As a consequence, similar nutrient outputs among the cultivars resulted in some cases and 'Susara' even presented a lower $\mathrm{Zn}$ value than 'Succession II'.

Protea nutrient removal reported in the literature is based on the removal by the harvested flowers, but they do not include the nutrients removed by the crop wastes, so that they do not illustrate completely the real removals. León (2011) had observed that the plant mass of 'Succession II' wastes (pruning and pinching out) represented an average of $54 \%$ of the total plant mass-produced throughout the crop cycle. In the present study, total nutrient removal could be calculated taking into account this percentage and extrapolating it to 'Tango' and 'Susara'. Such nutrient removal (flowering stems + crop wastes) would be $9.9 \mathrm{~g} \mathrm{~m}$ ${ }^{2} \mathrm{~N}, 0.76 \mathrm{~g} \mathrm{~m}^{-2} \mathrm{P}$ and $8.6 \mathrm{~g} \mathrm{~m}^{-2} \mathrm{~K}$ by 'Succession II', $7.6 \mathrm{~g} \mathrm{~m}^{-2} \mathrm{~N}, 0.59 \mathrm{~g} \mathrm{~m}^{-2} \mathrm{P}$ and $6.3 \mathrm{~g} \mathrm{~m}^{-2} \mathrm{~K}$ by 'Tango', and $9.0 \mathrm{~g} \mathrm{~m}^{-2} \mathrm{~N}, 1.01 \mathrm{~g} \mathrm{~m}^{-2} \mathrm{P}$ and $11.4 \mathrm{~g} \mathrm{~m}^{-}$ ${ }^{2} \mathrm{~K}$ by 'Susara'. These data are appropriate as a base to supply NPK fertilizers to avoid depletion of these nutrients in the soil. The N:P:K ratios should be 1:0.08:0.87 for 'Succession II', 1:0.08:0.83 for 'Tango' and 1:0.10:1,27 for 'Susara'. The remarks of Reid (2003) on the loss of effectiveness of fertilizers by leaching may be also taken into account.

\section{Acknowledgements}

This study was funded by the Agreement of the High Council of Scientific Research and the Cabildo Insular de La Palma. The authors are also grateful for the collaboration of the Proteas de La Palma Sociedad Cooperativa.

\section{References}

Álvarez, C.E., Fernández-Falcón, M. and Hernández, M.M. 2012. Plant nutrition, foliar standards, chlorophyll activity and soil nutrient status of two cultivars of Leucospermum cordifolium (Proteaceae). Cien. Invest. Agrar. 39: 105-116.

Cecil, J.S., Barth, G.E., Maier, N.A., Chviyl, W.L. and Bartetzko, M.N. 1995. Leaf chemical composition and nutrient removal by stems of Leucadendron cv. 'Silvan Red' and 'Safari Sunset'. Aus. J. Exp. Agric. 35: 547-55.

Chapman H.D. and Pratt, P.F. 1961. Methods of analysis for soils, plants and waters. California: University of California, Division of Agricultural Science. 309 p.

Claassens, A.S. 1986. Some aspects of the nutrition of proteas. Acta Hort. 185: 171179.

Cottenie, A. 1980. Soil and plant testing as a basis of fertilizer recommendations. Rome: FAO Soil Bulletin. $118 \mathrm{p}$.

Cresswell, C. 1991. Assessing the phosphorus status of Proteas using plant analysis. Sixth Biennial Conference. Perth: International Protea Association. pp. 303-310.

Fernández-Falcón, M., Alvarez, C.E. and Hernández M. 2008. Nutrient removal, 
fertilization, needs and yields of Protea plants cultivated in subtropical conditions. J. Plant Nutr. 31: 1018-1032.

González, A.C.E., Hernández, M. and FernándezFalcón, M. 2008. Nutrient distribution and stem length in flowering stems of protea plants. J. Plant Nutr. 31: 1624-1641.

Hawkins, H.J., Hettasch, H. and Cramer, M.D. 2007. Putting back what we take out, but how much? Phosphorus and nitrogen additions to farmed Leucadendron 'Safari Sunset' and Leucospermum 'Succession' (Proteaceae). Sci. Hort. 111: 378-388.

León, A.M.J. 2011. Study of growth, yield, photosynthetic capacity and fertilization of two cultivars of Leucospermum planted in clay soil directly or grafted on rootstock tolerant to clay soils. $\mathrm{PhD}$ thesis, University of La Laguna, Spain. 240 p.
Maier, N.A., Barth, G.E., Cecil, J.S., Chvyl, W.L. and Bartetzko, M.N. 1995. Effect of sampling time and leaf position on leaf nutrient composition of Protea 'Pink Ice'. Aust. J. Exp. Agric. 35: 275-283.

Malan, G. 2012. Protea cultivation. From concept to carton. Stellenbosch: SUN MeDIA. $297 \mathrm{p}$.

Mengel, K. and Kirkby, E.A. 2001. Principles of Plant Nutrition. Boston: Kluwer Academic Publishers. $849 \mathrm{p}$.

Montarone, M., Ziegler, M., Dridi, N. and Voisin, S. 2003. Comparison of mineral requirements of some cultivars in two proteaceae genera. Int. Protea News 44: 103-111.

Parvin, P.E. 1986. Use of tissue and soil samples to establish nutritional standards in protea. Acta Hort. 185: 145-153.

Reid, A. 2003. Nutrition and irrigation of proteas. Hort. News August, 2013. pp. 9-11. 